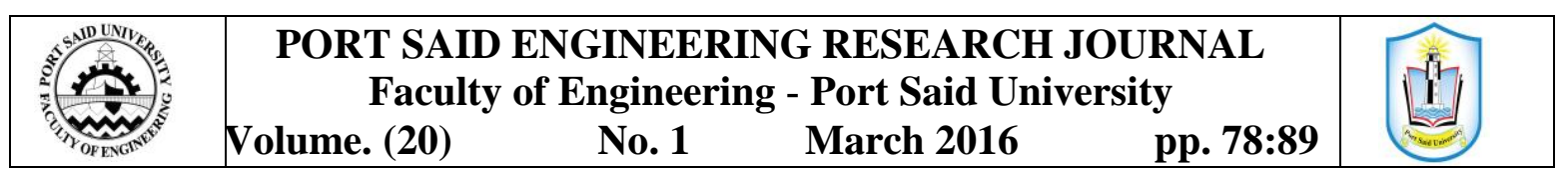

\title{
Properties of Geopolymer Mortar Containing Cement Kiln Dust (by- pass) as Partial Replacement Material for Low Calcium Fly Ash
}

\author{
H. A. Mohamadien'1, A. M. Heniegal², G. D. Abd Elhameed³, O. M. Omar²
}

\begin{abstract}
This paper presents the results of a study held to compare the properties of geopolymer mortar prepared with the use of class C fly ash. Utilization of cement kiln dust (by-pass) with its high alkali content in the activation of geopolymer mortar specimens to create nonconventional cementitious binders was investigated. Many different geopolymer mortar mixtures were tested, all prepared by using fly ash-to-sand ratio of 1:3. Mixtures evaluation was based upon replacing the fly ash with cement kiln dust (by-pass) in the selected mixtures. The cement kiln dust (by-pass) content percentages were $5 \%, 10 \%, 15 \%$ and $20 \%$ by weight of fly ash as a partial replacement. Alkaline liquid to fly ash ratio of 0.50 was used. At the used alkaline liquid to fly ash ratio, the strength developments have been observed at 3, 7, and 28 days. Geopolymer mortar specimens were prepared with different concentrations of NaOH solution of M10, M14 and M16 and were cured at $60{ }^{\circ} \mathrm{C}$ for 24 hours inside an oven. Thus, it is necessary to study the effects of the geopolymer binder on the behavior of compressive strength of geopolymer mortar. In this study, the Local Alkaline Activator in Egypt and Natural River sand as a fine aggregate in fly ash based-geopolymer mortar was investigated. This paper illustrates the development of mechanical properties. Hence it has been found that the compressive strength for geopolymer mortar at 28 days was in the range of $29.9 \mathrm{MPa}-41.6 \mathrm{MPa}$.
\end{abstract}

\section{INTRODUCTION}

The trading of Carbon Dioxide $\left(\mathrm{CO}_{2}\right)$ emissions is a critical factor for the industries, including the cement industries, as the greenhouse effect created by these emissions is considered to produce an increase in the global temperature that results in climate changes, D. Hardjito, [1]. The 'tradeable emissions' refers to the economic mechanisms that are expected to help the countries worldwide to meet the emission reduction targets established by the 1997 Kyoto Protocol.

Even though cement is a versatile construction material and is being used worldwide extensively, the greenhouse gas produced during its manufacturing process causes environmental impact. However, concrete made out of geopolymer technology replaces cement completely within it and thereby reduces the so called environmental deterioration, B. Joseph, and G. Mathew, [2].

Environmental worries related to Portland cement production, emission and disposal of cement kiln dust (bypass) are becoming gradually significant. Cement kiln dust (by-pass) is a fine-grained, particulate material easily entrained in the combustion gases moving through the kiln. It is composed primarily of variable mixtures of

1 Department of Civil Engineering, Faculty of Engineering, Suez Canal University, Egypt, E-mail: h_mohamadien@yahoo.com.

2 civil structures department, faculty of industrial education, Suez University, Suez, Egypt, E-mail: ashraf_henigal@yahoo.com.

3 Building Materials Research and Quality Control Institute, Housing and Building National Research Center, Egypt, E-mail: ghadadiaa1@yahoo.com). calcined and uncalcined feed materials, fine cement clinker, fuel combustion by-products and condensed alkali compounds. Cement kiln dust (by-pass) generation is responsible for a significant financial loss to the cement industry in terms of the value of raw materials, processing, energy usage, dust collection and disposal. Cement manufacturing plants generate approximately 30 million tons of cement kiln dust (by-pass) worldwide per year, Dyer et al., [3].

Maslehuddin et al., investigated the properties of cement kiln dust (by-pass) blended cement concretes. The percentages of cement kiln dust (by-pass) were $0 \%, 5 \%$, $10 \%$ and $15 \%$, replacing cement Type I and Type V. The results showed that the compressive strength of concrete specimens decreased with the increase in the quantity of cement kiln dust (by-pass). However, there was no significant difference in the compressive strength of the 0 and 5\% cement kiln dust (by-pass) cement concretes. A similar trend was noticed in the drying shrinkage strain. The chloride permeability increased and the electrical resistivity decreased due to the incorporation of cement kiln dust (by-pass). The performance of the 5\% cement kiln dust (by-pass) concrete was almost similar to that of the concrete without cement kiln dust (by-pass). Therefore, Maslehuddin et al., they suggested to limit the amount of cement kiln dust (by-pass) in concrete to $5 \%$, since the chloride permeability and electrical resistivity data indicated that the chances of reinforcement corrosion would increase in the case of $10 \%$ and $15 \%$ cement kiln dust (by-pass), Maslehuddin et al. [4]. 
Zainab H. A., abstracted that the compressive strength increased in the concrete mixtures including $10 \%$ and $20 \%$ CKD (as an addition of cement weight). A decrease in the compressive strength was noticed in the concrete mixtures including $10 \%$ and $20 \%$ CKD (as a replacement of cement weight). A similar trend was noticed in the splitting tensile strength and the increase in splitting tensile strength was less pronounced than that in compressive strength, Zainab H. A., [5].

Khater. H.M, concluded that the compressive strength increased in concrete mixtures including $10 \%$ and $20 \%$ cement kiln dust (by-pass) as an addition of cement weight. A reduction in compressive strength was noticed in concrete mixtures including $10 \%$ and $20 \%$ cement kiln dust (by-pass) as a replacement of cement weight, Khater. H.M, [6].

Geopolymer term was first introduced by Davidovits 1994, and 1984, [7]. Geopolymer is a class of aluminosilicate binders synthesized by activation of solid alumino-silicate source materials such as fly ash; granulated blast furnace slag obtained from industrial wastes or calcined clays like meta-kaolin, with an alkali metal hydroxide and silicate solution. These binders are currently attracting widespread attention due to their potential utilization as a high performance, environmental friendly and sustainable alternative to Portland cement. A geopolymer can also be defined as "the material that results from the geosynthesis of polymeric aluminosilicates and alkali-silicates, yielding a three-dimensional polymeric framework [8], [9].

Wallah and Rangan [10] reported that geopolymer concrete specimens exhibit extremely small changes in length and also show very little increase in mass after one year of exposure in sulphate solution. In another study by Bakharev [11] the author used various concentrations of sulphate solution to immerse the geopolymer materials prepared using different types of activating solutions.

This study was conducted to reveal the behavior of green geopolymer mortar incorporating various percentages of cement kiln dust (by-pass) as a partial replacement and evaluate its compressive strength, indirect tensile strength, sorptivity, water absorption and resistance to sulphate attack.

\section{RESEARCH PROGRAM}

This experimental study program was designed to achieve the research objectives. The program consists of three phases; phase I implies the use of fly ash based geopolymer mortar with fly ash to sand content ratio of 1:3 and with molarity of M10, M14 and M16. One mixture was controlled (normal mortar mixture) with Portland cement. Furthermore, the effect of the different contents of sodium silicate on the properties of mortar mixtures was studied and the most suitable mortar mixtures were chosen. Phase II, implies the repetition of the above experiment with the same components but with varied cement kiln dust (by-pass) content percentages of $5 \%$, $10 \%, 15 \%$ and $20 \%$ by weight of fly ash as a partial replacement for the chosen mixtures from phase I, and phase II. The mechanical properties of green mortar containing fly ash based-geopolymer mortar were measured in terms of compressive strength for all mixtures at 3, 7and 28 days. The following properties were also measured of the chosen mixtures: indirect tensile strength, sorptivity test at 56 days and water absorption, for all the selected mixtures of both the cement and geopolymer mortar.

\section{MATERIALS PROPERTIES}

Test specimens were prepared from the available materials which comply with the Egyptian Code No. 2032008 [12]. These include natural siliceous sand from Suez area and clean rounded fine aggregate with the size of 0.15 to $5 \mathrm{~mm}$ that was used. The physical properties of fine aggregate are shown in table (1). CEMI N42.5 was used from Suez Cement Company, the physical properties of ordinary portland cement are shown in Table (2). Sodium silicate solution (SSS) obtained from Egypt Global Silicates Company was also used, the chemical and physical properties of the (SSS) are shown in table (3). Sodium hydroxide in flake form $(\mathrm{NaOH}$ with $98-99 \%$ purity). The fly ash used in this research is class $\mathrm{F}$ fly ash according to the requirement of ASTM C618 Class F [4], its physical properties and XRF analysis are given in table (4) and table (5), respectively. Cement kiln dust (by-pass) was obtained from EL-Suez Cement Company where the percentage retained on sieve \#170 was less than $9 \%$. Accordingly the cement was expected to have a particles surface area around the range of $2980 \mathrm{~cm}^{2} / \mathrm{gm}$. Table (6) and (7) show the physical and chemical properties of cement kiln dust (by-pass), respectively.

Table 1: Physical properties of fine aggregate

\begin{tabular}{|l|c|c|}
\hline \multicolumn{1}{|c|}{ Property } & Results & Limits \\
\hline Specific Weight & 2.63 & $2.5-2.75 * *$ \\
\hline Bulk Density (t/m3) & 1.78 & ----- \\
\hline Fineness Modulus & 2.89 & ----- \\
\hline $\begin{array}{l}\text { Clay and Fine Dust } \\
\text { Content (\% By Volume) }\end{array}$ & 0.85 & $\begin{array}{c}\text { Not more } \\
\text { Than 3\%** }\end{array}$ \\
\hline
\end{tabular}

Table 2: Physical properties of ordinary Portland cement.

\begin{tabular}{|l|c|c|c|}
\hline \multicolumn{2}{|c|}{ Property } & Results & $\begin{array}{c}\text { Specifications } \\
\text { Limits* }\end{array}$ \\
\hline $\begin{array}{l}\text { Compressive } \\
\text { Strength of } \\
\text { Standard Mortar } \\
\text { (Mpa) }\end{array}$ & $\begin{array}{c}28 \\
\text { days }\end{array}$ & 39.7 & Not less than 36 \\
\cline { 2 - 4 } & $\begin{array}{l}\text { Fineness in terms of } \\
\text { S.S.A** (cm2/gm) }\end{array}$ & 31.4 & Not less than 18 \\
\hline $\begin{array}{l}\text { Setting Time ( } \\
\text { min ) }\end{array}$ & Initial & 75 & Not less than 45 \\
\cline { 2 - 4 } & Final & 480 & $\begin{array}{c}\text { Not more than } \\
600\end{array}$ \\
\hline
\end{tabular}

* Egyptian Stander Specifications ESS 4756-1/2009 [14]. 


\section{MIXING, MOLDING, AND CURING}

Table (8) represents the mixture proportions of the tested mixtures by weigh quantities for phase I, phase II and phase III for geopolymer mortar.

The preparation of chemicals and the mixing of fly ash based-geopolymer concrete involves two alkaline products, one of which (sodium hydroxide) is classified as a corrosive product which has the potential to seriously burn eyes, skin and internal organ, therefore special care has been taken during handling and working with the substance. These precautions included using a fume cabinet during the preparation of the sodium hydroxide solution and the mixing of mortar specimens, using high density polyethylene container for storage and wearing rubber gloves and goggle when handling the chemical and wet mixture.

Table 3: Chemical and physical properties of sodium silicate solution

\begin{tabular}{|l|c|}
\hline \multicolumn{1}{|c|}{ Product Name } & Data \\
\hline $\mathrm{SiO} 2 / \mathrm{Na} 2 \mathrm{O}$ ratio & 2.00 \\
\hline$\% \mathrm{Na} 2 \mathrm{O}$ & 14.70 \\
\hline$\% \mathrm{SiO} 2$ & 29.70 \\
\hline$\%$ Total solid & 44.40 \\
\hline$\%$ Water content & 55.55 \\
\hline$\%$ Water insoluble & 0.05 \\
\hline Baume & 50 \\
\hline $\begin{array}{l}\text { Specific gravity at }\left(20^{\circ} \mathrm{C}\right) \\
\text { g/cm3 }\end{array}$ & 1.526 \\
\hline Color and appearance & Clear white liquid \\
\hline PH & 12.7 \\
\hline
\end{tabular}

Table (4): Physical properties of the used fly ash

\begin{tabular}{|l|c|}
\hline \multicolumn{1}{|c|}{ Property } & Test Results \\
\hline Specific surface area $\left(\mathrm{cm}^{2} / \mathrm{gm}\right)$ & 3950 \\
\hline Bulk density $\left(\mathrm{kg} / \mathrm{m}^{3}\right)$ & 1250 \\
\hline Specific gravity & 2.5 \\
\hline Color & Light gray \\
\hline
\end{tabular}

Table (5): XRF Analysis for the used fly ash

\begin{tabular}{|l|c|c|}
\hline \multicolumn{1}{|c|}{ Oxide } & Content \% & $\begin{array}{c}\text { Limitation \% } \\
*\end{array}$ \\
\cline { 1 - 2 } $\mathrm{SiO}_{2}$ & 61.30 & \multirow{2}{*}{ Min. 70\% } \\
\cline { 1 - 2 } $\mathrm{Al}_{2} \mathrm{O}_{3}$ & 29.40 & \\
\cline { 1 - 2 } $\mathrm{Fe}_{2} \mathrm{O}_{3}$ & 3.27 & ----- \\
\hline $\mathrm{CaO}$ & 1.21 & ----- \\
\hline $\mathrm{MgO}$ & 0.75 & ---- \\
\hline $\mathrm{K}_{2} \mathrm{O}$ & 1.20 & Max. 3\% \\
\cline { 1 - 2 } $\mathrm{SO}_{3}$ & 0.003 & ---- \\
\hline $\mathrm{TiO}_{2}$ & 0.01 & Max. 1.5\% \\
\hline $\mathrm{Na}_{2} \mathrm{O}$ & 0.73 & Max. 0.05\% \\
\hline $\mathrm{Cl}$ & 0.04 & Max. 6\% \\
\hline $\mathrm{LOI}$ & 0.67 & \\
\hline
\end{tabular}

* According to the requirement of ASTM C618 Class F [13].
Table (6): Physical properties of the used cement kiln dust (by-pass).

\begin{tabular}{|l|c|}
\hline \multicolumn{1}{|c|}{ Property } & Test Results \\
\hline Specific surface area $\left(\mathrm{cm}^{2} / \mathrm{gm}\right)$ & 2980 \\
\hline Bulk density $\left(\mathrm{kg} / \mathrm{m}^{3}\right)$ & 1150 \\
\hline Specific gravity & 2.81 \\
\hline color & Light gray \\
\hline Physical Form & Powder \\
\hline
\end{tabular}

Table (7): XRF Analysis for the used cement kiln dust (by-pass).

\begin{tabular}{|l|c|}
\hline \multicolumn{1}{|c|}{ Oxide } & Content \% \\
\hline $\mathrm{SiO}_{2}$ & 16.65 \\
\hline $\mathrm{Al}_{2} \mathrm{O}_{3}$ & 4.48 \\
\hline $\mathrm{Fe}_{2} \mathrm{O}_{3}$ & 2.08 \\
\hline $\mathrm{CaO}$ & 41.87 \\
\hline $\mathrm{MgO}$ & 2.33 \\
\hline $\mathrm{K}_{2} \mathrm{O}$ & 5.20 \\
\hline $\mathrm{SO}_{3}$ & 2.15 \\
\hline $\mathrm{Na}_{2} \mathrm{O}$ & 4.16 \\
\hline $\mathrm{Cl}$ & 3.36 \\
\hline $\mathrm{LOI}$ & 11.82 \\
\hline
\end{tabular}

The mixing for all specimens was undertaken using manual mixing as following:

1- Fly ash was added to sand then mixed to dry materials for about 2 minutes.

2- Sodium hydroxide and sodium silicate were added to the dry materials with good mixing for 5 minutes.

3- The required water was added and mixed for 3 minutes again.

4- The mixtures were then placed in $70 \mathrm{~mm}$ cubic molds and compacted manually. The surface of the samples was covered with plastic bags before placing them in the oven to prevent rapid evaporation of liquids at different temperatures. Duplicate sets of specimens were then subjected to heat curing at $60{ }^{\circ} \mathrm{C}$ for 24 hour period by oven curing.

5- After that, all specimens were stored in room temperature prior to testing.

\section{DETAILS OF SPECIMEN}

Compression test at 3, 7, and 28 days was carried out on $70 * 70 * 70 \mathrm{~mm}$ cubes. Indirect tensile strength test at 28 days was carried out on $70 * 70 * 70 \mathrm{~mm}$ cubes. Sorptivity test at 28 days was carried out on $70 * 70 * 70 \mathrm{~mm}$ cubes. Water absorption test at 28 days was carried out on $70 * 70 * 70 \mathrm{~mm}$ cubes and resistance to sulphate attack test was carried out on $70 * 70 * 70 \mathrm{~mm}$ cubes and $25 * 25 * 285$ $\mathrm{mm}$ beam.

\section{RESULTS AND DISCUSSIONS}

\subsection{Compressive Strength of Geopolymer Mortar}


In this section, the experimental results are presented and discussed. Each point of the test data points plotted in the figures represents the mean value of the compressive strengths of three test cubes in a series. Table 9, Fig. 1, Fig. 2 and Fig. 3 show the results of the compressive strength for cement mortar specimens and geopolymar mortar specimens. The above experiment was done on the mortar containing fly ash-to-sand ratio of 1:3, and sodium hydroxide solution-to-sodium silicate solution ratio of $1: 1$, 1:2 and 1:3 with a molarity of M10, M14 and M16, respectively. The compressive strength of mortars are illustrated in Fig. 1, Fig. 2 and Fig. 3 which indicate that the compressive strength of OPC mortar is less than that of geopolymer mortar by $24 \%$ at 28 days. Thus, the compressive strength of Geopolymer mixtures is more than that of the OPC mixture in general. Besides, it can be observed that the strength of the geopolymer mortar specimens at the age of 7 days is greater than that of the OPC mortar specimens at the age of 28 days. The obtained results are in agreement with the results of published literatures [14] and [15].

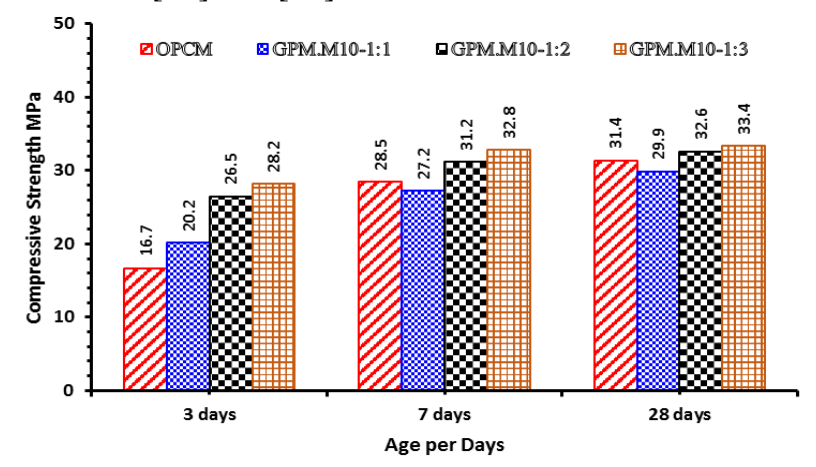

Fig. 1 Effect of sodium silicate solution-to-sodium hydroxide solution with molarity M10 on compressive strength compared to conventional cement mortar at 3, 7, and 28 days.

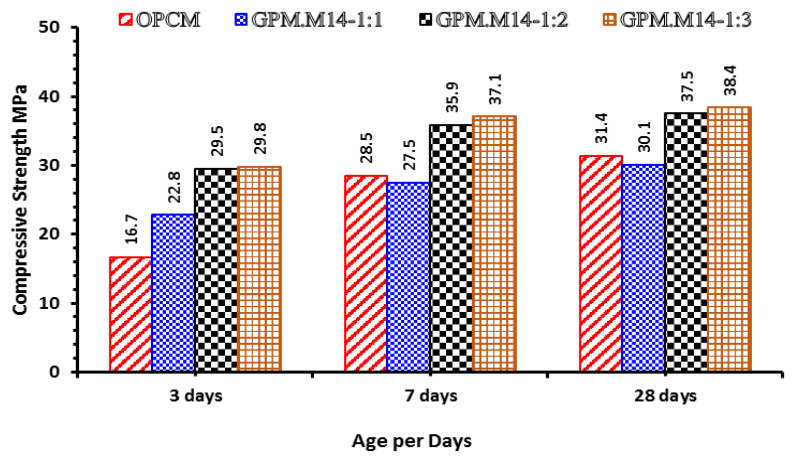

Fig. 2 Effect of sodium silicate solution-to-sodium hydroxide solution with molarity M14 on compressive strength compared to conventional cement mortar at 3, 7, and 28 days.

The compressive strength was studied at 3, 7, 28, and 91 days. From Table (9), Fig. 1, Fig. 2, and Fig. 3, the compressive strength of similar mixtures can be seen. According to these results, the compressive strength of geopolymer mortar mixture containing sodium silicate solution-to-sodium hydroxide solution of ratio $1: 3$ and molarity of M16 is higher than that of the mixture prepared with sodium silicate solution-to-sodium hydroxide solution of ratios 1:1 and 1:2 and molarity of M16 by about $20 \%$ and $4.2 \%$ at 28 days, respectively. From these results, it can be observed that there is a big difference between the sodium silicate solution-to-sodium hydroxide solution of ratio $1: 1$ and the sodium silicate solution-to-sodium hydroxide solution of ratio $1: 3$, and this difference is much lower than that of sodium silicate solution-to-sodium hydroxide solution of ratio 1:2. The same trend happened in the mixture containing molarity of M10 and M14, regarding the gain in compressive strength with time. From Fig. 1, Fig. 2 and Fig. 3, it can be seen that the increase of sodium silicate solution to sodium hydroxide solution ratio by mass up to a value of 2 significantly increases the compressive strength of fly ashbased geopolymer mortar and it slightly increases at the ratio of 3 in some mixtures.

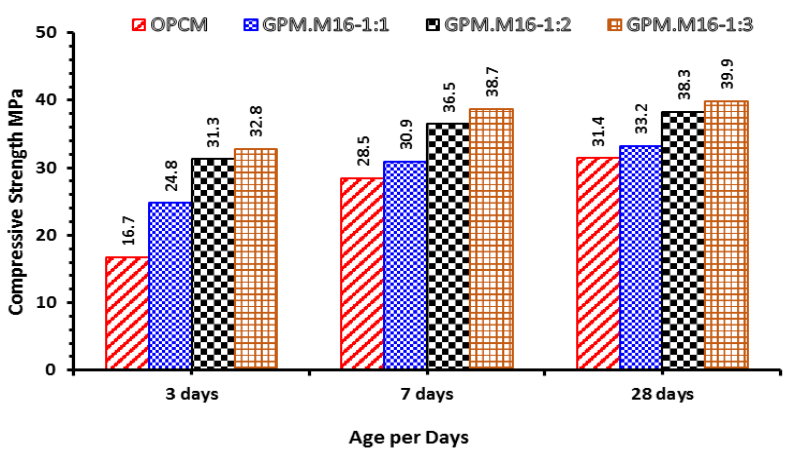

Fig. 3 Effect of sodium silicate solution-to-sodium hydroxide solution with molarity M16 on compressive strength compared to conventional cement mortar at 3, 7, and 28 days.

However, when the sodium silicate solution-to-sodium hydroxide solution ratio was 3 , the strength started to slightly increase due to the difficulty in compaction. It should be noted here that sodium hydroxide cost is less than sodium silicate and the mixture should therefore contain low sodium silicate solution-to-sodium hydroxide solution ratio while still giving the required strength and workability. For that purpose, mixtures that contain 1:2 ratio between sodium hydroxide solution and sodium silicate solution respectively has been selected. Furthermore, the increase in compressive strength is mainly due to the change in microstructure of geopolymer, which was influenced by the quantity of sodium silicate.

\subsection{Effect of $\mathrm{NaOH}$ Concentration on Compressive Strength}

From Table (9) it can be observed that the ratio of alkaline liquid-to-fly ash by mass was not varied. This ratio remained approximately around 0.5 , and fly ash-tosand ratio is constant 1:3. From Table (9), Mixture 1 represents OPC mortar while Mixtures 2, 3, and 4 
represent GP mortar with a concentration of sodium hydroxide of M10 and with sodium hydroxide solution-tosodium silicate solution ratio of $1: 1,1: 2$, and $1: 3$ respectively. The same trend is repeated in the Mixtures (5, 6, and 7), and the Mixtures (8, 9, and 10) with a concentration of sodium hydroxide of M14 and M16, respectively.
From Table (9), Fig. 1, Fig. 2, and Fig. 3, it can be observed that the compressive strength of geopolymer mortar increased with the increase in molarity of $\mathrm{NaOH}$ up to a value of 16 and on further increase of molarity (M) of $\mathrm{NaOH}$, the compressive strength slightly decreases.

Table (8), the mix proportions of the tested mixtures by weigh quantities for cement and geopolymer mortar for one liter.

\begin{tabular}{|c|c|c|c|c|c|c|c|c|c|c|}
\hline \multirow{2}{*}{$\begin{array}{l}\text { Mix } \\
\text { NO: }\end{array}$} & \multirow[b]{2}{*}{ Mix ID: } & \multirow[b]{2}{*}{ Molarity } & \multirow{2}{*}{$\begin{array}{c}\text { cement } \\
\text { kiln } \\
\text { dust } \\
\text { (by- } \\
\text { pass) } \\
\%\end{array}$} & \multirow{2}{*}{$\begin{array}{l}\text { FA } \\
(\mathrm{kg})\end{array}$} & \multirow{2}{*}{$\begin{array}{c}\text { cement } \\
(\mathrm{kg})\end{array}$} & \multirow{2}{*}{$\begin{array}{l}\text { cement } \\
\text { kiln } \\
\text { dust } \\
\text { (by- } \\
\text { pass) } \\
\text { (kg) }\end{array}$} & \multirow{2}{*}{$\begin{array}{l}\text { Water } \\
(\mathrm{kg})\end{array}$} & \multirow{2}{*}{$\begin{array}{c}\text { Fine } \\
\text { Aggregate } \\
(\mathrm{kg})\end{array}$} & \multicolumn{2}{|c|}{$\begin{array}{l}\text { Alkaline Liquid } \\
\qquad(\mathrm{kg})\end{array}$} \\
\hline & & & & & & & & & SSS & SHS \\
\hline 1 & OPCM & 0 & 0 & 0 & 0.49 & 0 & 0.245 & 1.47 & 0 & 0 \\
\hline 2 & GPM.M10-1:1 & \multirow{3}{*}{ M10 } & 0 & 0.53 & 0 & 0 & 0 & 1.61 & 0.133 & 0.133 \\
\hline 3 & GPM.M10-1:2 & & 0 & 0.53 & 0 & 0 & 0 & 1.61 & 0.177 & 0.088 \\
\hline 4 & GPM.M10-1:3 & & 0 & 0.53 & 0 & 0 & 0 & 1.61 & 0.200 & 0.066 \\
\hline 5 & GPM.M14-1:1 & \multirow{3}{*}{ M14 } & 0 & 0.53 & 0 & 0 & 0 & 1.61 & 0.133 & 0.133 \\
\hline 6 & GPM.M14-1:2 & & 0 & 0.53 & 0 & 0 & 0 & 1.61 & 0.177 & 0.088 \\
\hline 7 & GPM.M14-1:3 & & 0 & 0.53 & 0 & 0 & 0 & 1.61 & 0.200 & 0.066 \\
\hline 8 & GPM.M16-1:1 & \multirow{3}{*}{ M16 } & 0 & 0.53 & 0 & 0 & 0 & 1.61 & 0.133 & 0.133 \\
\hline 9 & GPM.M16-1:2 & & 0 & 0.53 & 0 & 0 & 0 & 1.61 & 0.177 & 0.088 \\
\hline 10 & GPM.M16-1:3 & & 0 & 0.53 & 0 & 0 & 0 & 1.61 & 0.200 & 0.066 \\
\hline 11 & OPCM-R5\% & 0 & 5 & 0 & 0.468 & 0.024 & 0 & 1.47 & 0 & 0 \\
\hline 12 & OPCM-R10\% & 0 & 10 & 0 & 0.443 & 0.049 & 0 & 1.47 & 0 & 0 \\
\hline 13 & OPCM-R15\% & 0 & 15 & 0 & 0.419 & 0.073 & 0 & 1.47 & 0 & 0 \\
\hline 14 & OPCM-R20\% & 0 & 20 & 0 & 0.394 & 0.098 & 0 & 1.47 & 0 & 0 \\
\hline 15 & $\begin{array}{c}\text { GPM.M10-1:2- } \\
\text { R5\% }\end{array}$ & \multirow{4}{*}{ M10 } & 5 & 0.506 & 0 & 0.026 & 0 & 1.61 & 0.177 & 0.088 \\
\hline 16 & $\begin{array}{l}\text { GPM.M10-1:2- } \\
\text { R10\% }\end{array}$ & & 10 & 0.479 & 0 & 0.053 & 0 & 1.61 & 0.177 & 0.088 \\
\hline 17 & $\begin{array}{l}\text { GPM.M10-1:2- } \\
\text { R15\% }\end{array}$ & & 15 & 0.453 & 0 & 0.079 & 0 & 1.61 & 0.177 & 0.088 \\
\hline 18 & $\begin{array}{l}\text { GPM.M10-1:2- } \\
\text { R20\% }\end{array}$ & & 20 & 0.426 & 0 & 0.106 & 0 & 1.61 & 0.177 & 0.088 \\
\hline 19 & $\begin{array}{l}\text { GPM.M14-1:2- } \\
\text { R5\% }\end{array}$ & \multirow{4}{*}{ M14 } & 5 & 0.508 & 0 & 0.026 & 0 & 1.61 & 0.177 & 0.088 \\
\hline 20 & $\begin{array}{l}\text { GPM.M14-1:2- } \\
\text { R10\% }\end{array}$ & & 10 & 0.481 & 0 & 0.053 & 0 & 1.61 & 0.177 & 0.088 \\
\hline 21 & $\begin{array}{c}\text { GPM.M14-1:2- } \\
\text { R15\% }\end{array}$ & & 15 & 0.454 & 0 & 0.08 & 0 & 1.61 & 0.177 & 0.088 \\
\hline 22 & $\begin{array}{l}\text { GPM.M14-1:2- } \\
\text { R20\% }\end{array}$ & & 20 & 0.428 & 0 & 0.106 & 0 & 1.61 & 0.177 & 0.088 \\
\hline 23 & $\begin{array}{l}\text { GPM.M16-1:2- } \\
\text { R5\% }\end{array}$ & \multirow{4}{*}{ M16 } & 5 & 0.509 & 0 & 0.026 & 0 & 1.61 & 0.177 & 0.088 \\
\hline 24 & $\begin{array}{l}\text { GPM.M16-1:2- } \\
\text { R10\% }\end{array}$ & & 10 & 0.482 & 0 & 0.053 & 0 & 1.61 & 0.177 & 0.088 \\
\hline 25 & $\begin{array}{c}\text { GPM.M16-1:2- } \\
\text { R15\% }\end{array}$ & & 15 & 0.455 & 0 & 0.08 & 0 & 1.61 & 0.177 & 0.088 \\
\hline 26 & $\begin{array}{l}\text { GPM.M16-1:2- } \\
\text { R20\% }\end{array}$ & & 20 & 0.428 & 0 & 0.107 & 0 & 1.61 & 0.177 & 0.088 \\
\hline
\end{tabular}


Table (9), Compressive Strength for Mixtures of Cement and Geopolymer Mortar.

\begin{tabular}{|c|c|c|c|c|c|c|c|c|}
\hline \multirow{2}{*}{$\begin{array}{l}\text { Mix } \\
\text { NO: }\end{array}$} & \multirow{2}{*}{ Mix ID: } & \multirow{2}{*}{$\begin{array}{c}\text { Molarit } \\
\mathrm{y}\end{array}$} & \multirow{2}{*}{$\begin{array}{l}\text { cemen } \\
\text { t kiln } \\
\text { dust } \\
\text { (by- } \\
\text { pass) } \\
\% \\
\end{array}$} & \multicolumn{3}{|c|}{$\begin{array}{c}\text { Compressive strength } \\
\text { MPa }\end{array}$} & \multirow{2}{*}{$\begin{array}{c}\text { Tensile } \\
\text { Strength } \\
\mathrm{MPa}\end{array}$} & \multirow{2}{*}{$\begin{array}{l}\text { Curing } \\
\text { Condition }\end{array}$} \\
\hline & & & & 3 days & 7 days & $\begin{array}{c}28 \\
\text { days }\end{array}$ & & \\
\hline 1 & OPCM & 0 & 0 & 16.7 & 28.5 & 31.4 & 2.8 & $\begin{array}{l}\text { Water } \\
\text { curing }\end{array}$ \\
\hline 2 & GPM.M10-1:1 & \multirow{3}{*}{ M10 } & 0 & 20.2 & 27.2 & 29.9 & - & \multirow{9}{*}{$\begin{array}{c}\text { Heat curing } \\
\text { at } 60^{\circ} \mathrm{C} \text { for } \\
24 \text { hours in } \\
\text { oven }\end{array}$} \\
\hline 3 & GPM.M10-1:2 & & 0 & 26.5 & 31.2 & 32.6 & 3.6 & \\
\hline 4 & GPM.M10-1:3 & & 0 & 28.2 & 32.8 & 33.4 & - & \\
\hline 5 & GPM.M14-1:1 & \multirow{3}{*}{ M14 } & 0 & 22.8 & 27.5 & 30.1 & - & \\
\hline 6 & GPM.M14-1:2 & & 0 & 29.5 & 35.9 & 37.5 & 4.4 & \\
\hline 7 & GPM.M14-1:3 & & 0 & 29.8 & 37.1 & 38.4 & - & \\
\hline 8 & GPM.M16-1:1 & \multirow{3}{*}{ M16 } & 0 & 24.8 & 30.9 & 33.2 & - & \\
\hline 9 & GPM.M16-1:2 & & 0 & 31.3 & 36.5 & 38.3 & 4.8 & \\
\hline 10 & GPM.M16-1:3 & & 0 & 32.8 & 38.7 & 39.9 & - & \\
\hline 11 & OPCM-R5\% & 0 & 5 & 14.6 & 29.3 & 32.7 & 3.1 & \multirow{4}{*}{$\begin{array}{l}\text { Water } \\
\text { Curing }\end{array}$} \\
\hline 12 & OPCM-R10\% & 0 & 10 & 13.2 & 24.8 & 28.1 & - & \\
\hline 13 & OPCM-R15\% & 0 & 15 & 11.4 & 13.8 & 21.9 & - & \\
\hline 14 & OPCM-R20\% & 0 & 20 & 9.1 & 10.1 & 20.3 & - & \\
\hline 15 & $\begin{array}{l}\text { GPM.M10-1:2- } \\
\text { R5\% }\end{array}$ & \multirow{4}{*}{ M10 } & 5 & 22.3 & 27.6 & 30.4 & 3.1 & \multirow{12}{*}{$\begin{array}{c}\text { Heat curing } \\
\text { at } 60^{\circ} \mathrm{C} \text { for } \\
24 \text { hours in } \\
\text { oven }\end{array}$} \\
\hline 16 & $\begin{array}{c}\text { GPM.M10-1:2- } \\
\text { R10\% } \\
\end{array}$ & & 10 & 18.3 & 24.5 & 26.6 & - & \\
\hline 17 & $\begin{array}{l}\text { GPM.M10-1:2- } \\
\text { R15\% }\end{array}$ & & 15 & 15.2 & 18.2 & 20.1 & - & \\
\hline 18 & $\begin{array}{l}\text { GPM.M10-1:2- } \\
\text { R20\% }\end{array}$ & & 20 & 13.5 & 16.5 & 18.2 & - & \\
\hline 19 & $\begin{array}{c}\text { GPM.M14-1:2- } \\
\text { R5\% } \\
\end{array}$ & \multirow{4}{*}{ M14 } & 5 & 24.2 & 29.5 & 33.1 & 3.8 & \\
\hline 20 & $\begin{array}{l}\text { GPM.M14-1:2- } \\
\text { R10\% }\end{array}$ & & 10 & 21.2 & 25.2 & 27.8 & - & \\
\hline 21 & $\begin{array}{c}\text { GPM.M14-1:2- } \\
\text { R15\% } \\
\end{array}$ & & 15 & 16.1 & 19.2 & 21.2 & - & \\
\hline 22 & $\begin{array}{l}\text { GPM.M14-1:2- } \\
\text { R20\% }\end{array}$ & & 20 & 15.5 & 18.2 & 19.5 & - & \\
\hline 23 & $\begin{array}{l}\text { GPM.M16-1:2- } \\
\text { R5\% }\end{array}$ & \multirow{4}{*}{ M16 } & 5 & 23.1 & 30.1 & 34.2 & 3.7 & \\
\hline 24 & $\begin{array}{l}\text { GPM.M16-1:2- } \\
\text { R10\% }\end{array}$ & & 10 & 20.2 & 25.2 & 29.1 & - & \\
\hline 25 & $\begin{array}{l}\text { GPM.M16-1:2- } \\
\text { R15\% }\end{array}$ & & 15 & 16.3 & 19.6 & 22.2 & - & \\
\hline 26 & $\begin{array}{l}\text { GPM.M16-1:2- } \\
\text { R20\% }\end{array}$ & & 20 & 16.2 & 19.2 & 20.2 & - & \\
\hline
\end{tabular}

$\mathrm{M}=$ molarity, $\mathrm{NH}=$ sodium hydroxide solution, $\mathrm{NS}=$ sodium silicate solution, $\mathrm{FA}=$ fly ash, $\mathrm{OPC}=$ ordinary Portland cement.

Fig. 4, illustrates the effect of sodium hydroxide concentration in sodium hydroxide solution-to-sodium silicate solution of ratio 1:2 on the compressive strength of fly ash-based geopolymer mortar. The test results shown in Fig. 4, demonstrate that the compressive strength of fly ash-based geopolymer mortar increases with the increase in the concentration of sodium hydroxide. The compressive strength of mortar specimens increases as the sodium hydroxide concentration in the aqueous phase increases from M10 to M16. Moreover, it slightly increases with the further increase in sodium hydroxide concentration from M14 to M16. However, there is 
variation in the strength between M10 and M14. It is accepted that an increase in alkali concentration enhances geopolymerization process resulting in an increase in the compressive strength of fly ash-based geopolymer mortar.

\subsection{Effect of cement kiln dust (by-pass) as a partial replacement on the compressive strength of OPC mortar}

Compressive strength test results of OPC mortar with different replacement percentages are presented in Table (9) and Fig. 5 for 5\%,10\%, 15\% and 20\% respectively. Using cement kiln dust (by-pass) up to $5 \%$ has increased the compressive strength of OPC mortar by about $2 \%$ and $4 \%$, at 7 and 28 days, respectively, when compared to the normal OPC mortar. Using cement kiln dust (by-pass) with level 10\%, $15 \%$ and $20 \%$ has decreased the compressive strength of normal OPC mortar by about $13 \%, 52 \%$ and 65 at 7 days when compared to the normal OPC mortar, respectively.

On the other hand, there is a reduction in compressive strength of about $11 \%, 30 \%$ and $36 \%$ at 28 days respectively, at the replacement level of $10 \%, 15 \%$ and $20 \%$, when compared to the normal OPC mortar.

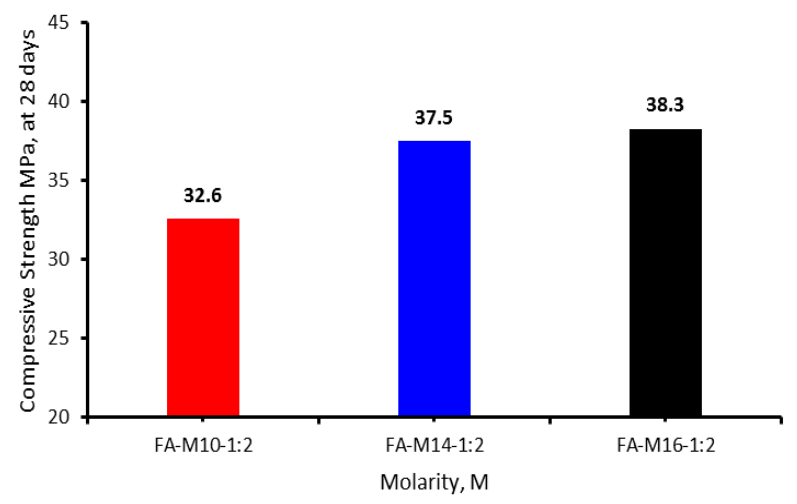

Fig. 4 Effect of Concentration in term of molarity (M) on Compressive Strength of geopolymer mortar.

The loss in the compressive strength at a replacement level of $10 \%, 15 \%$, and $20 \%$ can be related to the chemical effects of cement kiln dust (by-pass). Moreover, the percentage of free calcium hydroxide during the reaction of cement increases, when cement kiln dust (by-pass) increases similarly. The compressive strength of the hardened cement mortars containing OPC with different amounts of CKD is graphically represented as a function of curing time in Fig. 5, the compressive strength is increased with curing time for all the hardened cement mortars. However, the compressive strength is increased slightly with the increase of CKD content till up to $5 \%$. Above this percentage the compressive strength is dropped significantly. The reduction in the compressive strength is due to the decrease in the cement content and the increase in the free lime content in cement dust. The higher amount of calcium hydroxide has weakened the hardened OPC mortar matrix. The porosity also is increased, due to the high chloride $3.36 \%$, and sulfate $2.15 \%$, content in the CKD. The formation of these products enhances the crystallization of hydration products leading to the opening of the pore system. The crystallization of hydration products may be accompanied by an increase in the pore size due to the change in the packing between the crystals, which leads to a decline in the compressive strength. It can be said that the replacement of CKD by up to $5 \%$ in OPC can be utilized in the OPC mortar [15].

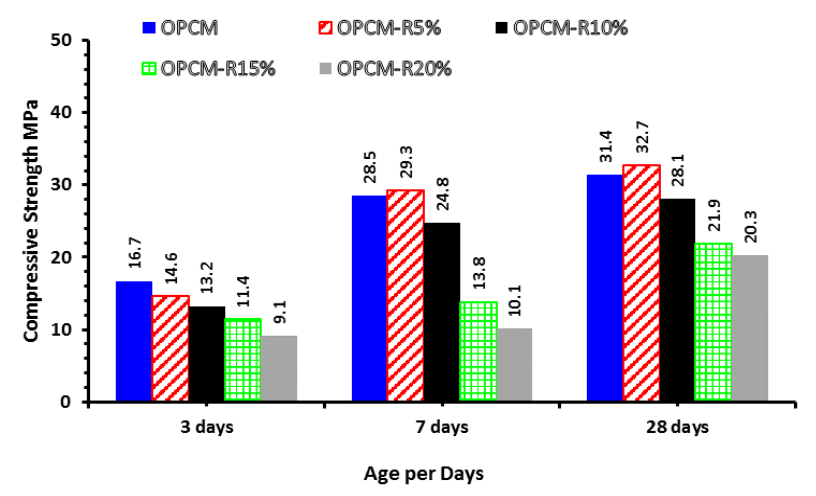

Fig. 5 Effect of cement kiln dust (by-pass) as a partial replacement on the compressive strength of conventional cement mortar at 3, 7, and 28 days.

\subsection{Effect of cement kiln dust (by-pass) as a partial replacement from fly ash on the compressive strength of GP mortar}

Compressive strength test results of geopolymer mortar with different replacement percentages are presented in Table (9). Fig. 6 for M10, Fig. 7 for M14 and Fig.8 for M16, for percentages of $5 \%, 10 \%, 15 \%$ and $20 \%$, respectively. Using cement kiln dust (by-pass) by up to $20 \%$ has decreased the compressive strength of geopolymer mortar by about $44 \%, 48 \%$ and $47 \%$, at 28 days with M10, M14 and M16, respectively, when compared to the normal geopolymer mortar at the same age. The reduction in the compressive strength is due to the decrease in the fly ash content and the increase in the free lime content in cement kiln dust (by-pass). The higher amount of calcium hydroxide has weakened the hardened geopolymer mortar matrix.

The loss in the compressive strength at a replacement level of $5 \%, 10 \%, 15 \%$ and $20 \%$ can be related to the chemical effects of cement kiln dust (by-pass). Moreover, the percentage of free calcium hydroxide during the reaction of cement increases, when cement kiln dust (bypass) increases, similar findings have been reported in earlier studies [6].

\subsection{Tensile Strength}

Table (9) and Fig. 9 show the results of the splitting tensile strength for cement mortar specimens and geopolymar mortar specimens. The above experiment has been done on the mortar containing cement kiln dust (bypass) as a partial replacement by $5 \%$ from cement weight 
in cement mortar, and 5\% from fly ash weight in geopolymer mortar.

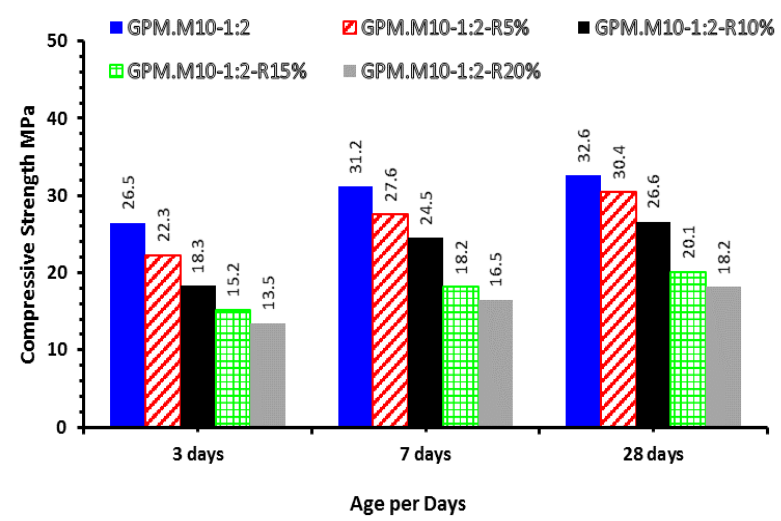

Fig. 6 Effect of cement kiln dust (by-pass) as a partial replacement on the compressive strength of geopolymer mortar with M10, at 3, 7, and 28 days.

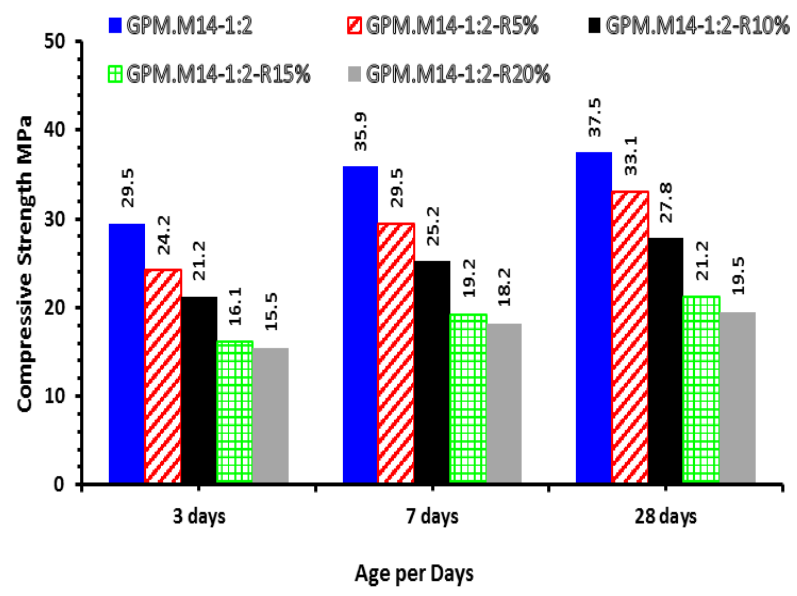

Fig. 7 Effect of cement kiln dust (by-pass) as a partial replacement on the compressive strength of geopolymer mortar with M14, at 3, 7, and 28 days.

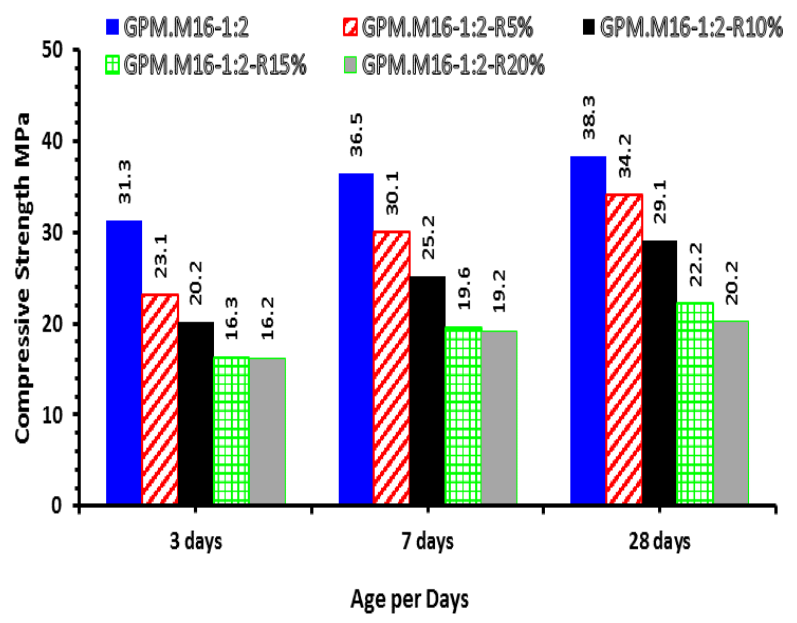

Fig. 8 Effect of cement kiln dust (by-pass) as a partial replacement on the compressive strength of geopolymer mortar with M16, at 3, 7, and 28 days.

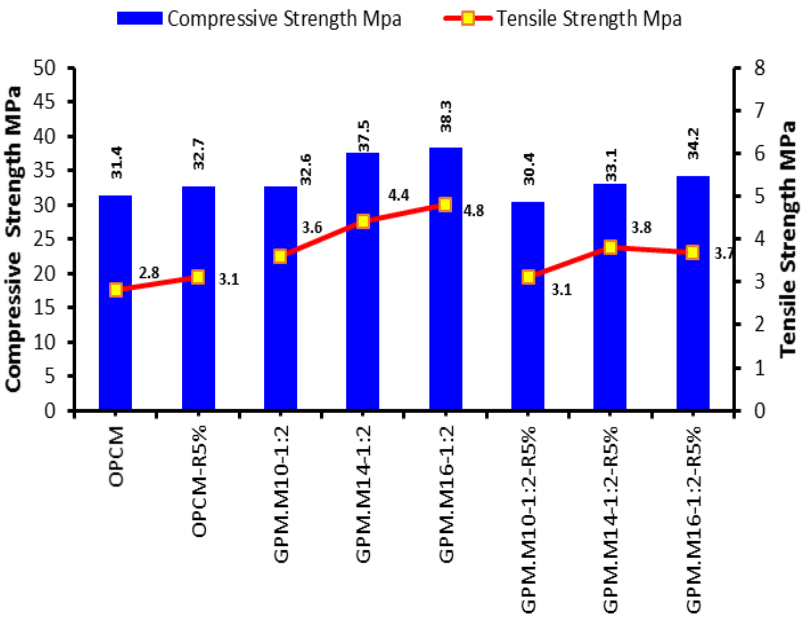

Fig. 9 Relationship between the tensile strength and compressive strength of cement and geopolymer mortar with and without cement kiln dust (by-pass) as a partial replacement, at 28 days.

The splitting tensile strength of geopolymer mortar is compared with the splitting tensile strength of conventional mortar at the same age.

Splitting tensile strength of geopolymer mortar with M10, M14 and M16 is presented in Fig. 9 and Table (9). It can be observed that, the splitting tensile strength is remarkably increased with the increas in the compressive strength at 28 days. Regarding the mixture containing molarity M10, M14 and M16 with sodium silicate solution-to-sodium hydroxide solution of ratio 1:2, the splitting tensile strength is about $11 \%, 11.7 \%$ and $12.5 \%$ from the compressive strength at 28 days, likewise the same trend happened in the mixtures containing cement kiln dust (by-pass) as a partial replacement by $5 \%$ from cement weight in cement mortar, and 5\% from fly ash weight in geopolymer mortar. From Table 11, it can be observed that, the splitting tensile strength for OPC mortar at 28 days is about $8.9 \%$ from the compressive strength, and is about $9.5 \%$ for the mixture containing cement kiln dust (by-pass) as a partial replacement by $5 \%$ from cement weight. Generally, the test results are given in Table (9), these test results show that the tensile splitting strength of geopolymer mortar is only a fraction of the compressive strength, as in the case of Portland cement mortar.

\subsection{Sorptivity test}

The sorptivity tests were carried out for duplicate specimens with dimensions of $70 * 70 * 70 \mathrm{~mm}$ cube in accordance with ASTM C1585-04. It was decided to adjust the specimens in an oven at $105^{\circ} \mathrm{C}$ until they reach a constant mass (less than $0.1 \%$ change in 24 hours) as the initial water content will affect the sorptivity result. The sides of the specimens were coated with epoxy to allow free water movement only through the bottom face (unidirectional flow). The specimens were then placed in a shallow tray layered with filter paper. The 
water level was adjusted such that only a 3-5 mm section of the specimen was immersed in water. The weights of specimens were measured after 5, 10 and 30 minutes, then measured hourly up to 6 hours, the initial weight also has been recorded. Weighing was done by removing specimens from the tray, shaking off excess surface moisture, and placing them with their dry surfaces on an electronic pan balance, so that the absorbing surface would not be touched, and then returning them to their sponges within $15 \mathrm{~s}$. The results were plotted against the square root of the time to obtain a slope of the best fit straight line. The absorption was evaluated using ASTM C1585-04 and calculated by equations: (1), [14]:

$$
\text { I = Mt } / \text { AP }
$$

Where

I, is the cumulative absorbed volume after time $\mathrm{t}$ per unit area of inflow surface $(\mathrm{mm} 3 / \mathrm{mm} 2)$.

$\mathbf{M t}$, the change in specimens mass at the time $\mathrm{t}$.

$\mathbf{P}$, the density of fluid.

A, the cross-sectional area in contact with fluid.

Sorptivity is a property associated with capillary effects. It is defined as the gradient of the volume of water absorbed per unit area of the surface and the square root of the absorption time. The movement of water into concrete is described by the classical square-root-time relationship.

These plots give the sorptivity for the selected mixtures, as shown in Fig. 10, at age 28 days. Each set of the plots shown refers to the average of the three samples tested from each mixture.

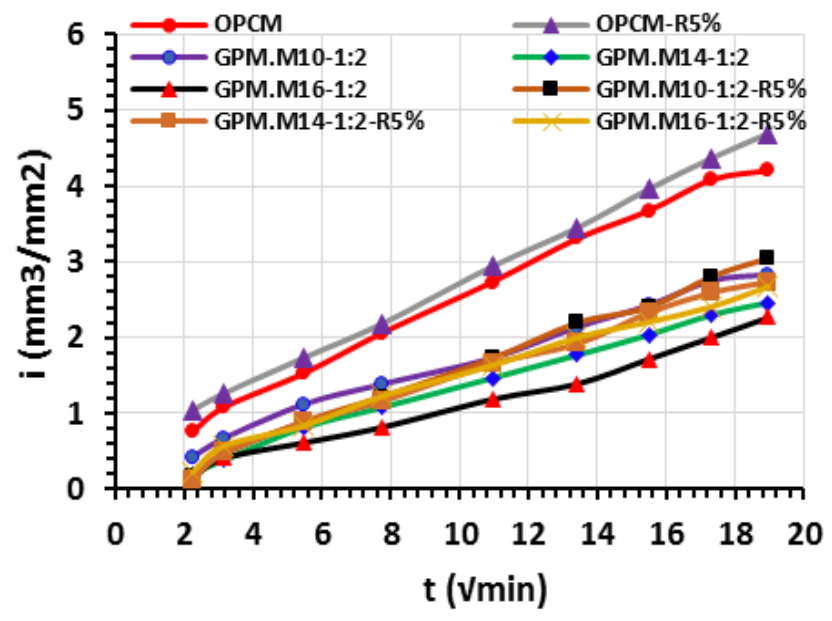

Fig. 10 Cumulative sorptivity per unit area with square root time for OPC mortar and geopolymer mortar, with and without cement kiln dust (by-pass) as a partial replacement, at 28 days.

In this relationship, water absorption into porous materials increases as the square root of the elapsed time " $t$ " increases. Assuming a constant supply of water at the inflow surface [8]. Typical plots of cumulative sorptivity against the square root of time are shown in Fig. 10.

Fig. 10, represents the curve of the cumulative mass gained per exposed surface area against square root of time where the slope of the linear portion is the measurement of sorptivity. It can be observed that, the sorptivity has remarkably decreased with the increase in compressive strength. It shows that the value of sorptivity decrease for geopolymer mortar more than for OPC mortar. Furthermore, when the concentration of $\mathrm{NaOH}$ increases in geopolymer mortar, the pore area becomes more nonpermeable, till upto a molarity of M16.

\subsection{Water absorption}

To determine the water absorption of the specimens, three cubes from each series were taken after curing at a temperature of $60{ }^{\circ} \mathrm{C}$ for 24 hours, and all specimens were then stored in room temperature prior to testing, and their weights were determined as initial weights. The samples were then immersed in water for 24 hours and their saturated surface dry weights were recorded as the final weights. Water absorption of specimens is reported as the percentage of weight increases. The temperature was kept under $60{ }^{\circ} \mathrm{C}$ to avoid any change in the structural configuration which may be caused due to the exposure to a temperature over the curing one. The procedures followed were after Debabrata and Somnath [17].

Water absorption was measured by using the following equation (2), [17].

\section{Water absorption=[(WS-WD)/WD]x100\%}

Where;

WS = weight of specimen after immersion in water for 24 hours.

WD $=$ weight of specimen after oven curing at $60{ }^{\circ} \mathrm{C}$ for 48 hours.

Values of water absorption were increased due to the replacement of cement kiln dust (by-pass) in geopolymer mortar while these values were significantly decreased for Geopolymer mortar without cement kiln dust (by-pass) as a partial replacement as shown in Fig. 11. Also, in case of the first mortar, the total penetrable pore area was significantly increased while poorer dry density was observed.

Water absorption of cement mortar mixture containing cement kiln dust (by-pass) as a partial replacement by $5 \%$ from cement weight is increased about $7 \%$ than that of the control mixture. On the other hand, when using cement kiln dust (by-pass) as a partial replacement for fly ash in the geopolymer mixtures with percentage up to $5 \%$, the Water absorption is increased by 5\%,7\% and $14 \%$ for the mixtures with the molarity of M10, M14, and M16 at the same ages, respectively. From Fig. 11, it can be observed that, the values of water absorption have remarkably decreased with the increase in compressive strength. The increase in water absorption is due to the decrease in the fly ash content and the increase in the free lime content in cement kiln dust (by-pass). The high amount of calcium hydroxide has weakened the hardened geopolymer mortar matrix and cement mortar matrix.

It is probable that the replacement of cement kiln dust (by-pass) as a partial replacement by $5 \%$ from fly ash weight in geopolymer mortar has caused less reaction and allowed less formation of $\mathrm{Si}-\mathrm{O}-\mathrm{Al}-\mathrm{O}$ structure which 
enters in the original structure of fly ash based geopolymer mortar and which makes the overall structure more porous. On the other hand, the addition of sand into the geopolymer binder disturbs the tetrahedral polymeric structure and makes a weak zone along with the intermediate surface. Hence cement kiln dust (by-pass) contains a less amount of reactive silica, it weakens the bond between the cement past and sand and that increases the intrusion of fluid into the core body.

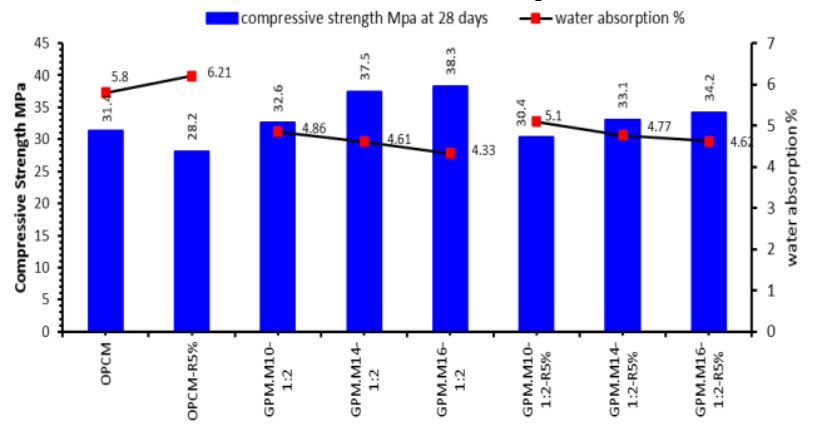

Fig. 11 effect of cement kiln dust (by-pass) as a partial replacement on the water absorption for OPC mortar and geopolymer mortar, at 28 days.

Obviously, the results in Fig. 11, indicates that the decrease of water absorption in the geopolymer mortar is more than that in cement mortar. Evidently, it decreases with increasing cement kiln dust (by-pass) as a partial replacement by $5 \%$ from cement or fly ash content. The increase in water absorption of fly ash geopolymer mortar with cement kiln dust (by-pass) as a partial replacement from fly ash is due to the fact that when a material with high calcium is replaced in a mixture specimen, it acts as a micro-filler of the matrix particles, which can increase the amount of water that fills-in the voids of the geopolymer mortar materials. However, replacing cement with cement kiln dust (by-pass) material would increase the wetted surface area and the amount of water adsorbed.

\subsection{Sulfate attack}

Fig. 12, Fig. 13, Fig. 14 and Fig. 15, show the expansion of mortars exposed to $10 \% \mathrm{Na}_{2} \mathrm{SO}_{4}$. Higher expansion existed in specimens that are placed in (NS) environment. Expansion observed in the 5\% cement kiln dust (by-pass) as a partial replacement for fly ash weight in geopolymer mortar prisms is similar and are marginally higher than the expansion observed in the 5\% cement kiln dust (by-pass) as a partial replacement for cement weight in cement mortar prisms. However, higher expansion was observed for OPC mortar prisms with and without cement kiln dust (by-pass) as a partial replacement for cement weight.

It can be seen from Fig. 12 that the expansion values at 25 weeks of exposure to $10 \% \mathrm{Na}_{2} \mathrm{SO}_{4}$ solution are $0.16 \%$, and $0.19 \%$ for mixtures with $0 \%$, and $5 \%$ cement kiln dust (by-pass) as a partial replacement for cement weight in cement mortar prisms, respectively. on the other hand, it can be seen from Fig. 13, Fig. 14 and Fig. 15, that the expansion values at 25 weeks of exposure to $10 \% \mathrm{Na}_{2} \mathrm{SO}_{4}$ solution are $(0.059 \%, 0.054 \%$, and $0.048 \%)$ and $(0.091 \%$,
$0.072 \%$, and $0.063 \%$ ) for mixtures with $0 \%$, and $5 \%$ cement kiln dust (by-pass) as a partial replacement for fly ash weight in geopolymer mortar prisms with molarity (M10, M14, and M16) and with sodium hydroxide solution-to-sodium silicate solution ratio of $1: 2$, respectively. Also, it can be observed that, the expansion values at 25 weeks has remarkably decreased with increasing the concentration of sodium silicate solution.

The replacement of 5\% of cement kiln dust (by-pass) produces an important increase in expansion of 19\% than the corresponding expansion of the traditional cement mortar. The higher expansion observed in the mortar containing 5\% cement kiln dust (by-pass) as a partial replacement for fly ash or cement weight may be attributed to the formation of secondary ettringite, which is characterized by expansion and cracking. In the mortar containing 5\% cement kiln dust (by-pass) as a partial replacement for cement weight, there is an increase in the part of the $\mathrm{Ca}(\mathrm{OH})_{2}$ produced by the hydration of cement. Therefore, the quantity of gypsum formed in the reaction between sulphates and $\mathrm{Ca}(\mathrm{OH})_{2}$, that is responsible for the formation of secondary ettringite, will be higher in the mortar containing 5\% cement kiln dust (by-pass) as a partial replacement for cement weight than that formed in the plain cement mortar that do not contain cement kiln dust (by-pass) as a partial replacement for cement weight. Further, the cement kiln dust (by-pass) as a partial replacement for fly ash or cement weight reduces the secondary CSH gel that also results in the densification of the hardened cement paste as it is deposited in the pores and weakens the paste-aggregate interface. These effects have increased significantly the diffusion of $\mathrm{SO}_{4}$ ions and explain the lower expansion observed in the mortar containing 5\% cement kiln dust (by-pass) as a partial replacement for cement weight against plain cement [18].

\section{Conclusions}

From the analysis and discussion of test results obtained from this research, the following conclusions can be drawn:

1- The use of fly ash based geopolymer as an alternative binder can help reducing the $\mathrm{CO}_{2}$ emission of mortar. The binder of geopolymer mortar is different from that of the ordinary Portland cement mortar, and the compressive strength of heat-cured fly ash-based geopolymer mortar does not depend on its age.

2- Higher concentrations (in terms of molar) of sodium hydroxide solution results in higher compressive strengths of fly ash-based geopolymer mortar, and the higher the ratio of sodium silicate-to-sodium hydroxide by mass, the higher is the compressive strength of the fly ash-based geopolymer mortar. 


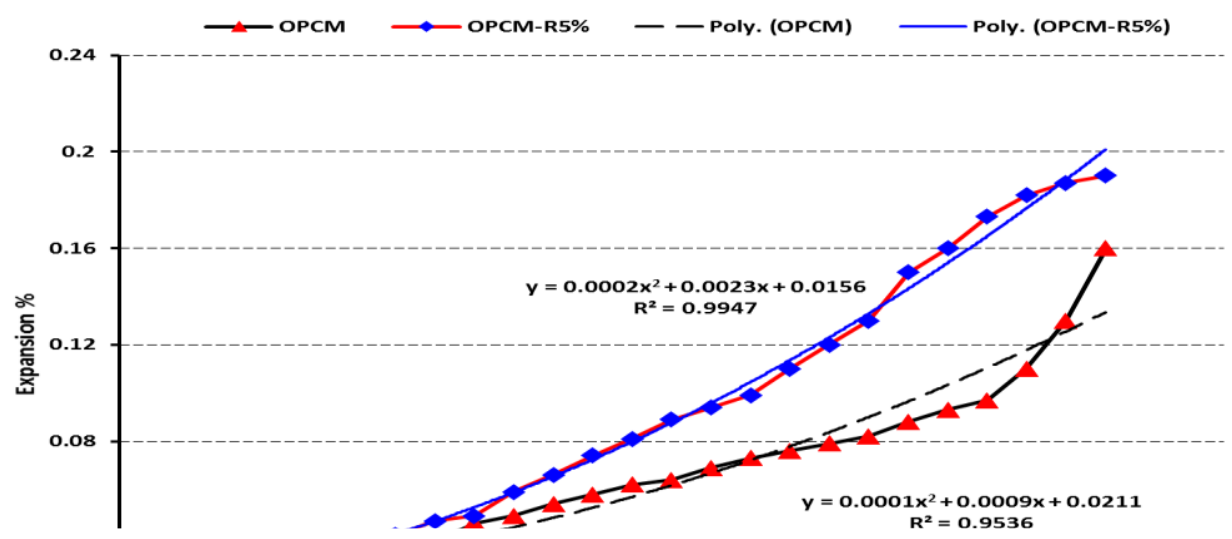

Fig. 12 Expansion of cement mortar bars made with cement and 5\% cement kiln dust (by-pass) as a partial replacement from cement weight.

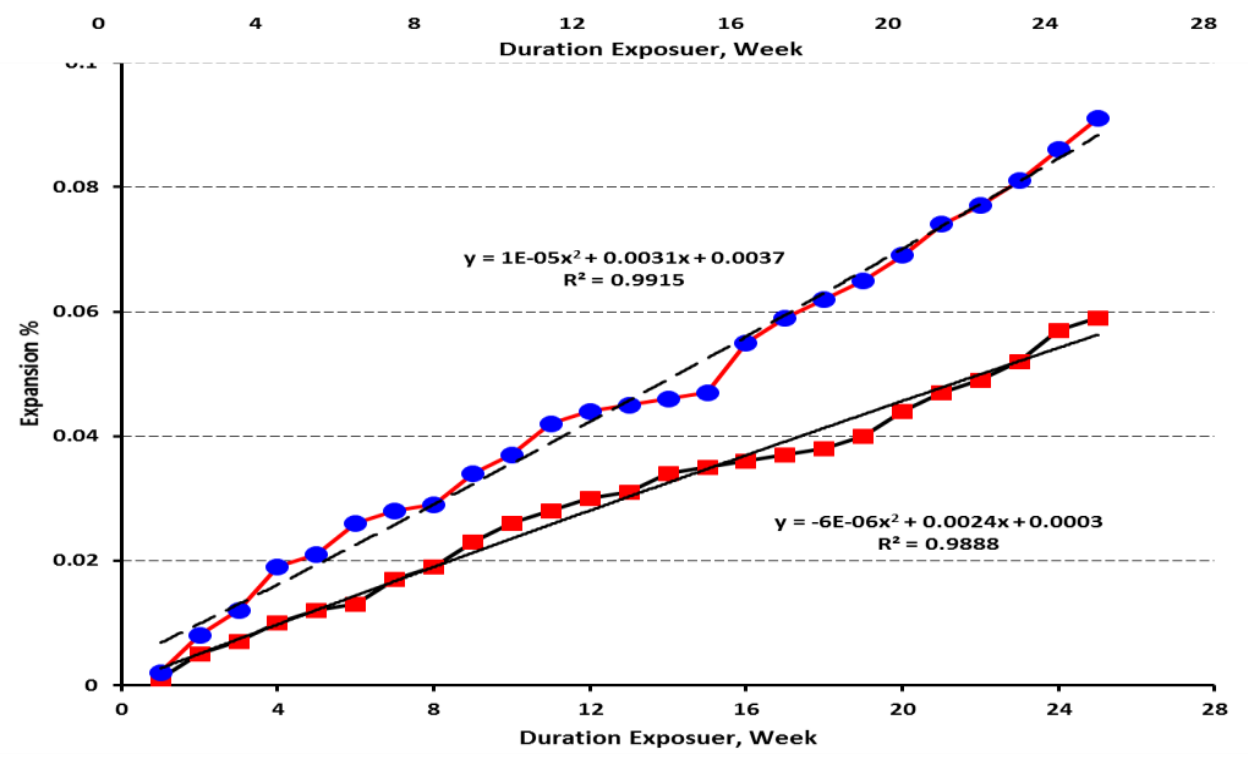

Fig. 13 Expansion of geopolymer mortar bars made with fly ash and 5\% cement kiln dust (bypass) as a partial replacement for fly ash weight with molarity M10.

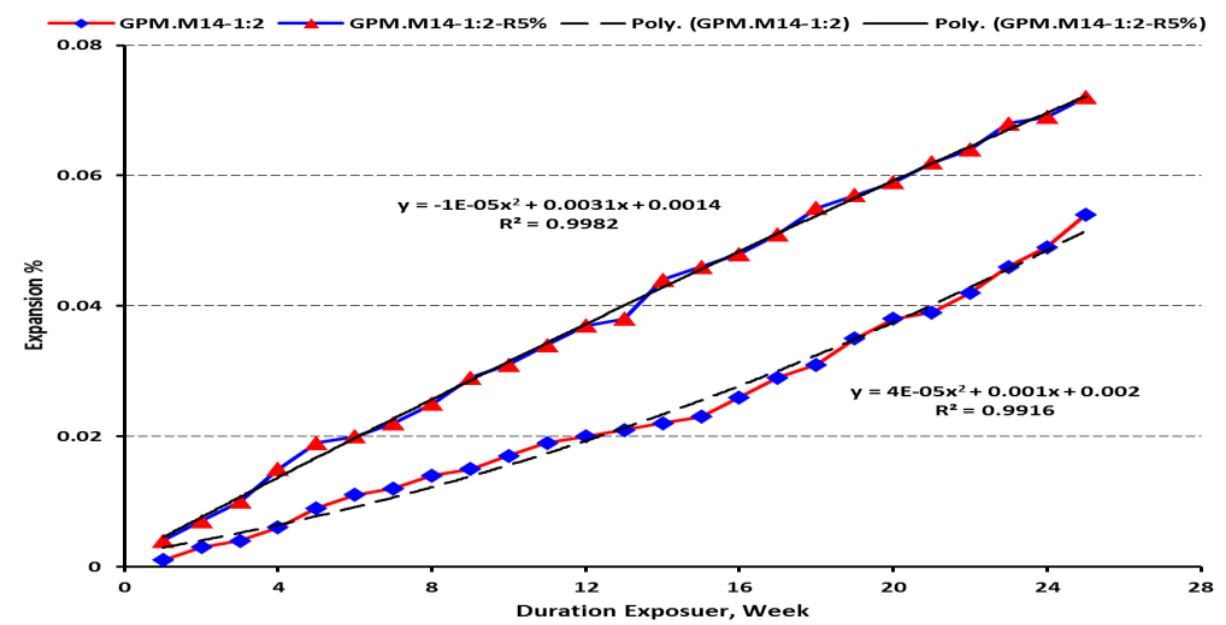

Fig. 14 Expansion of geopolymer mortar bars made with fly ash and 5\% cement kiln dust (bypass) as a partial replacement for fly ash weight with molarity M14 


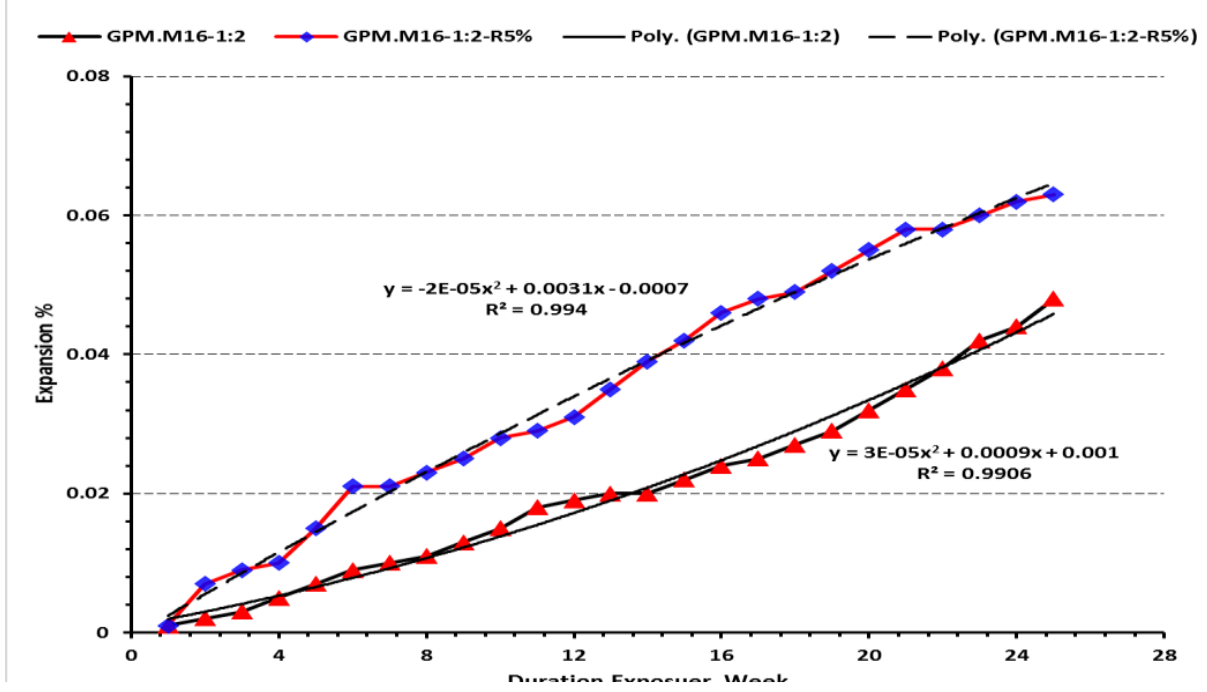

Fig. 15 Expansion of geopolymer mortar bars made with fly ash and 5\% cement kiln dust (bypass) as a partial replacement for fly ash weight with molarity M16.

3- The sorbativity and water absorption of the hardened fly ash-based geopolymer mortar decrease with the increase in compressive strength of the geopolymer mortar.

4- Using cement kiln dust (by-pass) as a partial replacement with a percentage upto $5 \%$ from cement weight increases the compressive strength about $4.1 \%$ more than that of the conventional Portland cement mortar.

5- Using cement kiln dust (by-pass) as a partial replacement with a percentage upto $20 \%$ from cement weight decreases compressive strength about $52 \%$ of that of the conventional geopolymer mortar with the molarity of M16 at 28 days.

\section{REFERENCES}

1- D. Hardjito, Studies on Fly Ash-Based Geopolymer Concrete. Ph. D. thesis, Curtin University of Technology, Australia, November 2005.

2- B. Joseph, G. Mathew, Influence of aggregate content on the behavior of fly ash based geopolymer concrete. Scientia Iranica, (2012), Vol. 19 (5), PP. 1188-1194.

3- T. D. Dyer, J. E. Halliday, R. K. Dhir, An investigation of the hydration chemistry of ternary blends containing cement kiln dust. Journal of Materials Science, Vol. 34, pp 4975-4983.

4- M. Maslehuddin, O.S.B. Al-Amoudi, M.K. Rahman, M.R. Ali, M.S. Barry, Properties of cement kiln dust concrete.

5- Z. H. Abdulabbas, Utilization of Cement Kiln Dust in Concrete Manufacturing. Jordan Journal of Civil Engineering, 2013 Vol. 7, pp. 111-125.

6- Khater. H.M, Effect of cement kiln dust on Geopolymer composition and its resistance to sulphate attack. International journal of civil and structural engineering, 2012, Vol. (2), PP. 749-762.

7- J. davidovits, properties of geopolymer cements. International conference on alkaline cement and concretes, kive state technical university, kive, ukraine, 1994, pp. 131-149.
8- D. Dutta, influence of silicious and calcious material as an additive on the performance of fly ash based geopolymer paste and mortar. MS.c of Civil Engineering (Structural Engineering), department of civil engineering faculty of engineering \& technology jadavpur university Kolkata, may 2010.

9- B. V. Rangan, Fly Ash-Based Geopolymer Concrete. Proceedings of the International Workshop on Geopolymer Cement and Concrete, Mumbai, India, December 2010, pp 68106.

10- S. E. Wallah and B. V. Rangan, Low calcium $\mathrm{fl}$ ash based geopolymer concrete: Long term properties, Research report GC2, Curtin University of Technology, Australia (2006).

11- T. Bakharev, Durability of geopolymer materials in sodium and magnesium sulphate solutions, Cement and Concrete Research 35 (2005) 1233-1246.

12- S. Mane, H.S. Jadhav, Investigation of Geopolymer Mortar and Concrete Under High Temperature. International Journal of Emerging Technology and Advanced Engineering, 2012, Vol. 2, pp. 384-390.

13- D. Hardjito, C. C. Cheak \& C. Ho Lee Ing, Strength and Setting Times of Low Calcium Fly Ash-based Geopolymer Mortar. Modern Applied Science, 2008, Vol. 2, pp. 3-11.

14- Egyptian Stander Specifications ESS 4756-1/2009.

15-S. Abd El-Aleem, M.A. Abd-El-Aziz, M. Heikal, H. El Didamony, effect of cement kiln dust substitution on chemical and physical properties and compressive strength of portland and slag cements. The Arabian Journal for Science and Engineering, 2005, Vol. 30, 263-273.

16- Egyptian Stander Specifications ESS 1106

17- D. Dutta, S. Ghosh, Effect of Lime Stone Dust on Geopolymerisation and Geopolymeric Structure, International Journal of Emerging Technology and Advanced Engineering, 2012, Vol. 2, pp.757-763.

18- A. M. Ramezanianpour, Sulfate Resistance and Properties of Portland- Limestone Cements, Ph. D. thesis, Department of Civil Engineering University of Toronto, March 2012. 